\title{
WSPÓŁCZESNA TREŚĆ POJECIA WZORU KULTURY GOSPODARCZEJ
}

\begin{abstract}
Pogonowska Barbara, Wspótczesna treść pojęcia wzoru kultury gospodarczej [The current understanding on the concept of the economy's culture pattern] edited by W. Banach - "Człowiek i Społeczeństwo", vol. XXXVIII, Poznań 2014, pp. 99-108, Adam Mickiewicz University Press. ISBN 978-83-232-2791-5. ISSN 0239-3271.

The article attempts at presenting a culture-oriented approach to economy culture' patterns. The notion of economy culture' pattern is conceived of as a set of normative beliefs that decide what kind of mutual rights and duties have a given subject of economic activities. The author asks questions about the cultural origins and normative assumptions of present day patterns.

Barbara Pogonowska, Uniwersytet Ekonomiczny w Poznaniu, Katedra Socjologii i Filozofii, ul. Towarowa 53, 61-896 Poznań, Poland.
\end{abstract}

\section{USTALENIA TERMINOLOGICZNE}

Podejmując tytułową tematykę należałoby się zastanowić nad wieloma kwestiami, takimi jak: czym są wzory kultury gospodarczej, w jaki sposób są kształtowane, jakie są ich bieżące, ale również historyczne źródła - a przede wszystkim jakie są fundamenty ich legitymizowania oraz jaką postać powinny posiadać i jakiego typu racje o tym decydują bądź winny decydować. Poszukując definicji bądź charakterystyki pojęcia wzoru gospodarczego, odnajdujemy $\mathrm{w}$ literaturze socjologicznej proponowane przez Piotra Sztompkę wyjaśnienie kategorii wzoru jako normatywnej regulacji wiążącej uczestników danej interakcji czy sytuacji społecznej ${ }^{1}$. W tym rozumieniu wzór wyznacza pewien pożądany, tj. powinnościowo określony, sposób postępowania, który zawiera się $\mathrm{w}$ wiązce wzajemnych uprawnień i obowiązków nałożonych na uczestników tej sytuacji społecznej. Owa norma-

\footnotetext{
${ }^{1}$ P. Sztompka, Socjologia. Analiza społeczeństwa, Znak, Kraków 2002, s. 90-92.
} 
tywna regulacja wywodzi się zaś z różnych systemów norm społecznych, takich jak zwyczaje społeczne, reguły moralne czy reguły prawne. Umieszczając znaczenie pojęcia wzoru $\mathrm{w}$ kulturze, a więc $\mathrm{w}$ systemie przekonań (tzw. „rzeczywistości myślowej”), wybitny socjolog wskazuje na narzucane jednostce wzory myślenia stanowiące układ „reguł dostarczających zewnętrznej, społecznej ramy odniesienia dla własnej indywidualnej aktywności"2. Następnie P. Sztompka przypomina, że posiadająca wyraźne aspekty powinnościowe kultura idealna (inaczej świadomość społeczna), której elementem są wzory, wiąże się z obiektami kultury materialnej, a przede wszystkim z działaniami jednostek, które przez owe wzory są wyznaczane 3 . Podobny sposób rozumienia znaczenia pojęcia wzoru, w tym wzoru kulturowego, przedstawia Stownik socjologiczny. W myśl proponowanej charakterystyki wzory kulturowe to społecznie, symbolicznie (kulturowo) ukształtowane i definiowane oraz uaktualniane ideały czy modele (wzory osobowe, wzory działań, wzory relacji itp.). W tym ujęciu wzory kulturowe określają pożądane sytuacje lub stany rzeczy, uznawane przez grupę bądź zbiorowość społeczną za godne naśladowania, najczęściej nieosiągalne w rzeczywistości i stanowiące specyficzne kryterium oceny istniejących zjawisk. Autorzy tej charakterystyki wzoru kulturowego zwracają uwagę, że pojęcie to, wywodzące się ze "szkoły Boasa", używane jest zamiennie z terminem konfiguracja kulturowa, styl czy profil kultury 4 . Nie wnikając $w$ dalsze sposoby konceptualizacji tego pojęcia, można przyjąć, korzystając równolegle z ujęcia Sztompki oraz założeń i rozstrzygnięć poznawczych społeczno-regulacyjnej koncepcji kultury J. Kmity, iż wzór kultury gospodarczej to pożądany, tj. powinnościowo określony sposób postępowania jednostek $w$ tej dziedzinie kultury (tzw. kultury materialnej), którą jest sfera wytwarzania (produkcji) dóbr i usług oraz ich dystrybuowania i konsumpcji. Ponieważ „obszar produkcji, wymiany oraz konsumpcji nie jest autonomiczny względem pozostałych form społecznej działalności ludzi, jakkolwiek jest podstawą ludzkiej egzystencji w jej jednostkowym i zbiorowym wymiarze" 5 , kształtowanie się wzorów kultury gospodarczej, a co za tym idzie, konstytuowanie i utrwalanie sposobów codziennego działania w sferze wytwarzania dóbr i usług oraz ich dystrybuowania i konsumpcji, będzie zależne od postaci przekonań obecnych w dziedzinie szeroko pojmowanej kultury symbolicznej, zwłasz-

2 Ibidem, s. 257.

${ }^{3}$ Ibidem, s. 258.

4 Stownik socjologiczny, red. K. Olechnicki, P. Załęcki, Wydawnictwo Graffiti BC, Torun 2002, s. 253.

${ }^{5} \mathrm{~W}$. Kot, Wybrane relacje poznawcze w obrębie wiedzy filozoficznej, socjologicznej i ekonomicznej, [w:] Gospodarka a społeczeństwo, red. J. Sikora, Wydawnictwo i Drukarnia UNI-DRUK s.j., Poznań 2010, s. 98. 
cza zaś w układzie przekonań wyznaczających wartości nadrzędne danej kultury: „Gospodarka jest zatem podstawowym źródłem wiedzy potocznej, stale - pośrednio czy bezpośrednio - obecnej w komunikacji społecznej, gdzie dokonuje się obieg i wykorzystanie spostrzeżeń techniczno-praktycznych, manifestacji obyczajowych, postaw światopoglądowych, stosunku do dzieł sztuki itp." 6 . Sposób postępowania w sferze gospodarowania, który zawiera się w wiązce wzajemnych uprawnień i obowiązków nałożonych na uczestników tej sytuacji społecznej, jest więc zależny od sfery wartości nadrzędnych, tych, które są rekonstruowane i konceptualizowane przez różnorodne doktryny ekonomiczne, socjologiczne i filozoficzne (a także religijne) stanowiące bazę wyjaśniającą dla rozpoznawania i rozumienia sfery gospodarowania.

Wzory kultury gospodarczej będą zatem (co oczywiste) komponentem kultury gospodarczej, którą tworzy układ przekonań dyrektywalnych oraz normatywnych (wartościujących) wskazujących pożądane i niepożądane stany rzeczy/wartości-cele występujące w obszarze działań ekonomicznych oraz sposoby osiągania bądź - odpowiednio - unikania owych stanów rzeczy. Zgodnie z ujęciem J. Kmity warunkiem kulturowego statusu tego układu przekonań, w tym przekonań tworzących wzory kultury gospodarczej, jest ich - $\mathrm{w}$ danym czasie i $\mathrm{w}$ danej zbiorowości - respektowanie (praktykowanie) przez podmioty działań ekonomicznych, przy czym faktyczna regulacja tej aktywności podlega tylko w części świadomej refleksji owych podmiotów.

\section{FUNDAMENTY AKSJOLOGICZNE}

Przyjmując, że fundamentem legitymizowania funkcjonujących w obrębie danego społeczeństwa wzorów kultury gospodarczej jest sfera światopoglądowa, należałoby ustalić, które nurty socjoekonomii czy filozofii gospodarczej są obecnie ważne, które z nich mają pozycję dominującą, a które przyjmują postać idei alternatywnych. Pozostawiając analizę aksjologicznej zawartości tych nurtów na marginesie7, można jedynie zasygnalizować to,

6 Ibidem, s. 96.

7 Przykładowa propozycja listy doktryn socjoekonomicznych (liberalizm klasyczny, społeczna doktryna Kościoła, idee socjaldemokratyczne), czyli zbiorów filozoficzno-socjologicznych (aksjologicznych) rozstrzygnięć dotyczących charakteru społeczeństwa i natury ludzkiej oraz typu relacji wiążących oba te elementy w procesach gospodarowania jest zawarta $\mathrm{w}$ pracy: B. Pogonowska, Kategoria racjonalności w teoriach przedmiotowych makroekonomii, Wydawnictwo Akademii Ekonomicznej w Poznaniu, Poznań 1996, s. 119-138, natomiast nurtów filozofii gospodarczej ((neo)liberalizm, komunitaryzm, ordoliberalizm, antyglobalizm), 
że od typu wartości światopoglądowych obecnych w kulturze i regulujących współczesną gospodarkę, a przez owe nurty rejestrowanych i konceptualnie uzasadnianych, niewątpliwie zależeć będzie kształt wzorów kultury gospodarczej. W wielkim uproszczeniu kwestię tę ujmując: będą to wzory wzmacniające dobro (zyski, korzyści, satysfakcję) podmiotu jednostkowego (firmy, instytucji, menedżera, inwestora, pracownika, konsumenta), za które odpowiedzialna jest dziś głównie klasyczna idea homo oeconomicus i zdobywająca uznanie promowana przez ekonomię behawioralną koncepcja zwierzęcych instynktów, bądź też wzory eksponujące różnorodnie pojmowane dobro wspólne (całego społeczeństwa, społeczności lokalnej, ludzkości i przyrody w wymiarze globalnym), którego realizacja wymaga od wszystkich uczestników respektowania norm współodpowiedzialności, solidarności, obywatelskości, partycypacji, samorządności i innych kompetencji etycznych.

W związku z wielością aksjologicznych fundamentów oraz wielowymiarowością sfery gospodarowania pojawia się - $\mathrm{w}$ odniesieniu do analizy wzorów kultury gospodarczej - wiele pytań. Czy chodzi o wzory kultury gospodarczej praktykowane przez przedsiębiorcę, pracownika, menedżera/ przywódcę i konsumenta czy też o wzory charakterystyczne dla podmiotów typu MSP, wielkie firmy i korporacje? Czy z punktu widzenia skomplikowanej sytuacji współczesności pożądana jest wielość wzorów kultury gospodarczej czy też ich unifikacja? Jaka jest skala praktykowania dających się obecnie wyróżnić wzorów kultury gospodarczej i na jakich poziomach społeczeństwa gospodarującego są one respektowane (polskiego, zachodniego, światowego)? I na koniec, w jakiej formie przejawia się relacja genetycznej zależności wchodzących tu w grę przekonań kulturowych, tzn. czy uznamy, że współczesne wzory kultury gospodarczej nawiązują bądź powinny nawiązywać do wzorów przeszłości (i jakiego typu, tj. z jakiego kręgu kulturowego pochodzących), są ich pożądaną dekonstrukcją, czy też stanowią niekorzystną dla kultury erozję zastanej tradycji (np. bardzo często podkreślany jest upadek protestanckiego etosu pracy i charakterystycznego dlań jednostkowego systemu wartości).

\section{WSPÓŁCZESNE WZORY KULTURY GOSPODARCZEJ}

Można sądzić, że ze względu na procesy globalizacji i jedynie nieznaczne „zarysowanie” przez doświadczenie kryzysu fundamentów gospo-

w artykule: H. Zboroń, B. Pogonowska, Wspótczesne doktryny filozofii gospodarczej, [w:] Elementy etyki gospodarki rynkowej, red. B. Pogonowska, PWE, Warszawa 2004, s. 89-117. 
darczego neoliberalizmu współczesne podmioty gospodarcze ulegają standaryzacji także i w zakresie praktykowanego wzoru / praktykowanych wzorów gospodarczych. Mimo niewątpliwie panującej różnorodności wzorów, dominującym, a nadto wzmacnianym i utrwalanym jako właściwy (racjonalny $\mathrm{w}$ sensie zgodności $\mathrm{z}$ „prawami” rynku) przez system edukacji zwłaszcza wyższych uczelni ekonomicznych, jest wzór działania przedsiębiorcy, menedżera, inwestora oraz konsumenta oparty na paradygmacie neoliberalizmu gospodarczego. $\mathrm{W}$ tym rozumieniu wzorzec kreuje pewien pożądany, tj. powinnościowo określony sposób postępowania, który (zgodnie $\mathrm{z}$ ujęciem Sztompki) zawiera się $\mathrm{w}$ wiązce wzajemnych uprawnień i obowiązków nałożonych na uczestników sytuacji społecznej, którą to wiązkę wyznaczają "obiektywne" (umieszczone poza światem kultury) mechanizmy rynkowe. I tak norma maksymalizowania zysku bądź osiągania wzrostu wartości rynkowej jako najwyższy cel funkcjonowania firmy, ideał racjonalności mikroekonomicznej, wzorzec homo oeconomicus (także w odniesieniu do konsumenta - podstawowym kryterium podejmowanych decyzji jest cena danego dobra), indywidualistyczna koncepcja społeczeństwa i gospodarki, urynkowienie i deregulacja życia społeczno-gospodarczego jako najbardziej słuszna i prorozwojowa zasada przemian kulturowych, teza o „skapywaniu" bogactwa, traktowanie jednostek na rynku pracy jako zasobów (stających się niekiedy łatwym do obniżenia kosztem), zgoda na tzw. nieuniknione efekty zewnętrzne rynku, brak zobowiązań na rzecz wspólnoty i środowiska naturalnego, o ile nie jest to określone wymogami prawnymi itd. - dostarczają zewnętrznej, społecznej ramy odniesienia dla własnej indywidualnej ekonomicznej aktywności podmiotów. Poczynione przez Elaine Sternberg ustalenia w odniesieniu do zakresu badań etyki biznesu rekonstruują ów neoliberalny wzór kultury gospodarczej: „Etyka biznesu zajmuje się tylko tymi problemami etycznymi, które powstają przy wykonywaniu czynności podejmowanych przez przedsiębiorstwo, kontrowersjami etycznymi, przed którymi przedsiębiorstwa stają jako przedsiębiorstwa. $\mathrm{Na}$ przykład pytanie: czy przedsiębiorstwo winno brać udział w łapownictwie, stanowi typową kwestię etyki biznesu. Lecz pytanie: czy dana osoba winna pracować w firmie, która zajmuje się łapownictwem, kupować od niej czy w nią inwestować, zazwyczaj kwestią etyki biznesu nie jest" 8 . Analizując casus firm sprzedających podejrzane materiały, np. pornografiaę, bron, wyroby tytoniowe, Sternberg stwierdza: "Jak wszystkie pozostałe przedsiębiorstwa, tak firmy sprzedające produkty działają etycznie jako przedsiębiorstwa,

${ }^{8}$ E. Sternberg, Czysty biznes. Etyka biznesu w działaniu, przeł. P. Łuków, Wydawnictwo Naukowe PWN, Warszawa 1998, s. 270-271. 
jeżeli zdążają do maksymalizowania długoterminowej wartości dla właściciela przy poszanowaniu wymogów sprawiedliwości dystrybutywnej i zwyczajnej przyzwoitości; są one nieetyczne, gdy warunki te naruszają" oraz „....jeżeli działalność taka nie jest z konieczności nieuczciwa czy niesprawiedliwa, nie opiera się na przymusie lub nie sprzeciwia się prawu, to odpowiedź będzie zależała od wielu czynników. Niektóre względy mają przede wszystkim charakter rozstrzygnięć naukowych i ekonomicznych: stopień szkodliwości danego produktu dla zdrowia lub środowiska naturalnego, prawdopodobieństwo zaszkodzenia, wielkość towarzyszących szkodzie możliwych korzyści ekonomicznych"9. Pozostaje tylko stwierdzić, że taki właśnie wzór wzajemnych uprawnień i obowiązków nałożonych na uczestników sytuacji rynkowej jest dziś dominujący i w dużej mierze postrzegany jako oczywisty, tj. niekwestionowalny.

Jednakże od lat dziewięćdziesiątych XX wieku pojawiają się $\mathrm{w}$ przestrzeni społecznej alternatywne wzory kultury gospodarczej. Ich początkiem są ruchy alter- (oraz anty-) globalistyczne kwestionujące triumf neoliberalnej ideologii oraz ideologii nieuchronności dominacji reguł światowego rynku w imię haseł w rodzaju: „wyobraź sobie lepszy świat” czy „świat to nie towar"10 - a zatem wskazujące pożądane sytuacje lub stany rzeczy zawierające się w pojęciu wspólnego dobra. Kolejną grupę alternatywnych wzorów kultury gospodarczej promują nurty związane ze społeczną odpowiedzialnością biznesu, w tym głównie kantowska (socjalna) orientacja CSR. Wiązka wzajemnych uprawnień i obowiązków nałożonych na uczestników tej sytuacji społecznej wyznacza taki sposób prowadzenia działań gospodarczych, aby możliwe były stany rzeczy, takie jak: urzeczywistnianie idei równoległego realizowania wartości ekonomicznych, społecznych i ekologicznych, wypełnianie przez podmioty gospodarcze zobowiązań wyrażanych $\mathrm{w}$ koncepcie corporate citizenship czy osiąganie wspólnego dobra w rozumieniu zasad zrównoważonego rozwoju i rozmaitych projektów globalnych o charakterze etycznym.

Sektor ekonomii społecznej, będącej odpowiedzią na wyzwania związane z narastaniem problemów niektórych grup społecznych, „radzi sobie z zaspokajaniem potrzeb, którym nie może sprostać działalność innych sektorów, a chodzi mianowicie o spójność społeczną i dbałość o tworzenie miejsc pracy, zachęcanie do przedsiębiorczości, budowanie społeczeństwa pluralistycznego, uczestniczącego, demokratycznego i opartego na solidar-

9 Ibidem, s. 272.

10 A. Domosławski, Świat nie na sprzedaż. Rozmowy o globalizacji i kontestacji, Wydawnictwo Sic!, Warszawa 2000. 
ności"11. Podmioty ekonomii społecznej działają na rynku i korzystają z narzędzi i technologii biznesu, ale przyjmują prymat działania na rzecz ludzi (członków, podopiecznych) nad maksymalizacją zysku: „Oznacza to, że dla jednostek ekonomii społecznej istotne znaczenie - obok celu gospodarczego ma misja społeczna"12. Jest to zatem wzór kultury gospodarczej nastawiony na osiąganie wartości kwalifikujących wspomniane sytuacje lub stany rzeczy jako pożądane, a także uznawane przez pewną grupę bądź zbiorowość społeczną za godne naśladowania i stanowiące specyficzne kryterium oceny istniejących zjawisk. Kryterium to rozstrzygać będzie, czy doświadczane przez ich uczestników sytuacje społeczne sprzyjają budowie społeczeństwa obywatelskiego, większej spójności społecznej, pełnemu zatrudnieniu, walce przeciwko biedzie, marginalizacji i wykluczeniu społecznemu, w tym realizacji określonych priorytetów Unii Europejskiej.

Interesującym i ważnym świadectwem kształtowania się wzorów kultury gospodarczej skupionych wokół idei wspólnego dobra są niewątpliwie praktyki inicjowane przez ruch Fair-Trade ${ }^{13}$, wyrażające ideę solidarności z podmiotami gospodarczymi, które zostały zdominowane przez wielkie korporacje i sieci dystrybucji oraz - w konsekwencji - zmarginalizowane w przestrzeni globalnego rynku. Podobnie - działania określane mianem konsumpcji etycznej, tj. praktyki nabywania dóbr i usług wytworzonych zgodnie ze standardami społecznie odpowiedzialnego biznesu i bojkotowania firm niespełniających tych standardów, w imię współodpowiedzialności za wspólne dobro.

Na zakończenie tego fragmentu można zadać pytanie, na ile doświadczenie ostatniego światowego kryzysu uświadomiło potrzebę dokonania zmiany hierarchii wartości, także w sensie postaci wzorów kultury gospodarczej. Sądzę, że można wziąć pod uwagę to, iż wśród postrzeganych przyczyn kryzysu wskazuje się na krytykowany wzór mikroracjonalności ekonomicznej i niedopasowanie promowanych przez nią wartości do współczesnych oczekiwań kultury - a także na dostrzeżenie czy odrodzenie potrzeby aksjologicznego uprawomocnienia celów makroekonomicznych oraz zauważenie konieczności tego uprawomocnienia na poziomie globalnych wymiarów gospodarowania, co także ma związek ze wzorami kultury gospodarczej.

11 W. Kwaśnicki, Gospodarka społeczna z perspektywy ekonomii liberalnej, „Trzeci Sektor” 2005, nr 2, za: B. Szopa, Intelektualne korzenie ekonomii społecznej, [w:] Wokót ekonomii społecznej, red. M. Frączek, J. Hausner, S. Mazur, Małopolska Szkoła Administracji Publicznej, Uniwersytet Ekonomiczny w Krakowie, Kraków 2012, s. 14.

${ }^{12}$ portal.ngo.pl [dostęp: 20.01.2014].

13 J.E. Stiglitz, A. Charlton, Fair trade. Szansa dla wszystkich, przeł. A. Szeworski, Wydawnictwo Naukowe PWN, Warszawa 2007. 


\section{TRADYCJA WZORÓW KULTURY GOSPODARCZEJ}

Pytanie, które pojawiło się już wcześniej, wiąże się z dylematem, czy dzisiaj jest możliwy (i pożądany) powrót do któregoś z klasycznych, tj. obecnych w przeszłości, wzorów kultury gospodarczej. Sądzę, że warto w tym momencie zastanowić się nad możliwościami, jakie „oferuje” często przywoływany etos protestancki lub mieszczański eksponujący cenne wartości, np. uczciwość, pracowitość, oszczędność, zapobiegliwość czy skromność. Zachodzi podejrzenie, iż jednak odrodzenie owego etosu nie spełniłoby należących do grupy - alternatywnych (tak jak wzory) oczekiwań społecznych ze względu na nieobecność kategorii wspólnego dobra w tym etosie. Daniel Bell, analizując cywilizację mieszczańską, stwierdza: „Kapitalizm jest systemem społeczno-ekonomicznym nastawionym na wytwarzanie towarów $\mathrm{w}$ drodze racjonalnego rachunku kosztów i cen oraz na akumulację kapitału w celu jego reinwestowania. Ten szczególny, nowy sposób gospodarowania sprzągł się z określoną kulturą i strukturą osobowości. W kulturze była to koncepcja samorealizacji jednostki, jej wyzwolenia z tradycyjnych ograniczeń i więzi (rodzinnych i pochodzenia) tak, by mogła kształtować sama siebie wedle własnej woli. Strukturę osobowości określała natomiast norma samokontroli i opóźnionej gratyfikacji, norma celowego zachowania w dążeniu do dobrze określonego celu. To właśnie wzajemny związek systemu ekonomicznego, kultury i struktury osobowości kształtował cywilizację mieszczańską"14. Sądzę, że charakterystyczny dla XIX wieku nawyk porównywania nakładów i efektów, a także systematycznego poszukiwania najskuteczniejszych metod postępowania - czyli racjonalne (w sensie Maxa Webera) podejście do gospodarki, a później i do innych dziedzin życia, nie jest do pogodzenia z wartościami kultury nie tylko zachodniego społeczeństwa. Mam na myśli narastający sprzeciw wobec dyktatu owej racjonalności formalnej (kalkulacyjnej) i zwrócenie się ku - uwzględniającej społeczny, $\mathrm{w}$ tym przede wszystkim aksjologiczny, kontekst - racjonalności substancjalnej (materialnej).

Podobny problem pojawia się, gdy przywołamy zespół wartości zachodnioeuropejskiego XIX-wiecznego mieszczaństwa w ujęciu Marii Ossowskiej ${ }^{15}$. Czy wartości w rodzaju: świętość hierarchicznie i patriarchalnie pojmowanego życia rodzinnego, własność jako wyznacznik statusu, w życiu publicznym - konstytucyjny porządek polityczny, wolność, rów-

${ }_{14}$ D. Bell, Kulturowe sprzeczności kapitalizmu, przeł. S. Amsterdamski, Wydawnictwo Naukowe PWN, Warszawa 1994, s. 15.

${ }^{15}$ J. Kochanowicz, Mieszczaństwo, [w:] Encyklopedia socjologii, t. 2, Oficyna Naukowa, Warszawa 1999, s. 236. 
ność wobec prawa, lecz również przekonanie, że członkowie klas niższych winni „znać swoje miejsce”, postrzegane jako oczywiste, bowiem wywodzące się z naturalnego porządku, mogą pełnić rolę aksjologicznego fundamentu współczesnych wzorów kultury gospodarczej? Z pewnością nie, ponieważ z punktu widzenia dokonanych przemian społecznych będą się jawić jako archaiczne. Ponadto owe wartości są od wspólnego dobra nie tylko oddalone, ale wręcz kategorię tę eliminują. Natomiast takie wartości, jak: talent i praca jako warunki osobistego sukcesu, solidność w interesach czy szacunek dla sztuki, niewątpliwie mogłyby i powinny owe wzory współtworzyć. Dodajmy jeszcze pogląd D. Bella, który poszukując źródeł kapitalizmu we wzorze promowanym przez etykę kalwińską i protestancką, zauważa, że nacisk na ascetyzm, systematyczną pracę i religijną legitymizację dążenia do bogactwa ulega $\mathrm{w}$ pewnym momencie erozji i pojawia się hedonizm oraz - drugie źródło kapitalizmu - zachłanność (ów - według Wernera Sombarta - faustowski pęd ucieleśniony w nowożytnej gospodarce i technice, który za cel stawiał całkowite przekształcenie natury) ${ }^{16}$. A jak stwierdza Joseph Schumpeter, giełda jest marnym substytutem świętego Graala17.

Sądzę, że trudne wyzwania współczesności doświadczane w wymiarze lokalnym i globalnym, takie jak rosnące nierówności społeczne, bezrobocie, wymogi ochrony środowiska, fale migracji "ludzi zbędnych”, erozja systemu zabezpieczeń społecznych itd., oraz narastający, choć rozproszony w publicznej przestrzeni, opór społeczny wobec obecnych zasad organizacji obszaru gospodarowania doprowadzą do ukształtowania zupełnie nowego, tj. nieznanego w przeszłości wzoru bądź wzorów kultury gospodarczej. Można też mieć nadzieję, iż fundament układu wzajemnych uprawnień i obowiązków nałożonych na uczestników kultury gospodarczej wyznaczą wartości wyartykułowane w dokumentach w rodzaju: Global Compact, Biała Księga, dokumenty Komisji Unii Europejskiej promujące idee społecznej odpowiedzialności biznesu czy postulaty Manifestu Global Compact ONZ "Globalna etyka gospodarcza: skutki dla światowego biznesu" (2009), uznające aksjologię zasady człowieczeństwa, nakazu niestosowania przemocy i szacunku dla życia, sprzeciwu wobec pracy przymusowej i pracy dzieci, niezgody na kary cielesne oraz niekorzystne dla zdrowia warunki pracy, troski o bezpieczeństwo produktów, o trwałe i zrównoważone traktowanie środowiska naturalnego, zasady odpowiedzialności, uczciwości, transparentności, tolerancji, wzajemnego szacunku i partnerstwa.

\footnotetext{
${ }^{16}$ D. Bell, op. cit., s. 17 i n.

17 Za: ibidem, s. 24.
} 
W konkluzji tekstu warto przywołać znaczące wyniki badania przeprowadzonego wśród studentów na temat pożądanego wzoru firmy i przełożonego ${ }^{18}$. Wynika z nich, że dla młodych ludzi najważniejsze jest to, aby szef dbał o pracowników (97\%), firma była odpowiedzialna społecznie $(91 \%)$ i działała ekologicznie (77\%). Natomiast za mniej ważne atuty uznano wysoką pozycję przedsiębiorstwa na rynku (74\%) czy międzynarodowe środowisko pracy $(66 \%)$.

\section{BIBLIOGRAFIA}

Bell D., Kulturowe sprzeczności kapitalizmu, przeł. S. Amsterdamski, Wydawnictwo Naukowe PWN, Warszawa 1994.

Domosławski A., Świat nie na sprzedaż. Rozmowy o globalizacji i kontestacji, Wydawnictwo Sic!, Warszawa 2000.

Kochanowicz J., Mieszczaństwo, [w:] Encyklopedia socjologii, t. 2, Oficyna Naukowa, Warszawa 1999.

Kot W., Wybrane relacje poznawcze w obrębie wiedzy filozoficznej, socjologicznej i ekonomicznej, [w:] Gospodarka a społeczeństwo, red. J. Sikora, Wydawnictwo i Drukarnia UNI-DRUK s.j., Poznań 2010.

Młodzi 2012 o ekologii i społecznej odpowiedzialności biznesu, wrzesień 2013, TNS Polska na zlecenie firmy Henkel, „Gazeta Wyborcza” 8.10.2013.

Pogonowska B., Antyglobalizm, [w:] Elementy etyki gospodarki rynkowej, red. B. Pogonowska, PWE, Warszawa 2004.

Pogonowska B., Kategoria racjonalności w teoriach przedmiotowych makroekonomii, Wydawnictwo Akademii Ekonomicznej w Poznaniu, Poznań 1996.

Słownik socjologiczny, red. K. Olechnicki, P. Załęcki, Wydawnictwo Graffiti BC, Toruń 2002.

Sternberg E., Czysty biznes. Etyka biznesu w działaniu, przeł. P. Łuków, Wydawnictwo Naukowe PWN, Warszawa 1998.

Stiglitz E., Charlton A., Fair trade. Szansa dla wszystkich, przeł. A. Szeworski, Wydawnictwo Naukowe PWN, Warszawa 2007.

Szopa B., Intelektualne korzenie ekonomii społecznej, [w:] Wokót ekonomii społecznej, red. M. Frączek, J. Hausner, S. Mazur, Małopolska Szkoła Administracji Publicznej, Uniwersytet Ekonomiczny w Krakowie, Kraków 2012.

Szopa B., Teorie ekonomiczne a ekonomia społeczna, [w:] Wokót ekonomii społecznej, red. M. Frączek, J. Hausner, S. Mazur, Małopolska Szkoła Administracji Publicznej, Uniwersytet Ekonomiczny w Krakowie, Kraków 2012.

Sztompka P., Socjologia. Analiza społeczeństwa, Znak, Kraków 2002.

Zboroń H., Pogonowska B., Wspótczesne doktryny filozofii gospodarczej, [w:] Elementy etyki gospodarki rynkowej, red. B. Pogonowska, PWE, Warszawa 2004.

portal.ngo.pl [dostęp: 20.01.2014].

18 Młodzi 2012 o ekologii i społecznej odpowiedzialności biznesu, wrzesień 2013, TNS Polska na zlecenie firmy Henkel, „,Gazeta Wyborcza” 8.10.2013. 